\title{
Halal Cosmetics Adoption Among Young Muslim Consumers in Malaysia: Religiosity Concern
}

\author{
Mohezar,S. (Corresponding author) \\ Faculty of Business \& Accountancy, University Malaya \\ 50603 Kuala Lumpur, Malaysia \\ Tel: +603-79673836 E-mail: suhanamohezar@um.edu.my \\ Suhaiza Zailani \\ Faculty of Business \& Accountancy, University Malaya \\ 50603 Kuala Lumpur, Malaysia \\ Tel: +603-79673860 E-mail:shmz@um.edu.my \\ Zainorfarah Zainuddin \\ Faculty of Arts \& Social Science, University Malaya \\ 50603 Kuala Lumpur, Malaysia \\ Email: zainorfarah@siswamail.um.edu.my
}

\begin{abstract}
The global increase in Muslim populations and purchasing power has created a new demand for halal cosmetic product development. While the introduction of new product may facilitate companies in gaining competitive advantage, the failure rates of product innovation is also high. Owing to such interests, this paper aims to determine factors that motivate young adult Muslim consumers in the emerging market to adopt halal cosmetics. This study expands prior research by integrating Diffusion of Innovation theory and religiosity dimension to explain the antecedents of halal cosmetics adoption among young Muslim consumers. Data were collected from 238 young Muslim consumers using questionnaires distributed at a number of supermarkets in Kuala Lumpur. The conceptual model and hypotheses developed were tested using partial leased square.Our results demonstrate that perceived product characteristics, social influence and consumer innovativeness influence young Muslim consumers to adopt halal cosmetics products. This study also report religiosity as moderator between these three predictors and halal cosmetic adoption.
\end{abstract}

Keywords: Consumer preferences, Halal cosmetics, innovations, cosmetics

\section{Introduction}

Cosmetics and personal could be referred to products that are applied to the human body for cleansing, beautifying, promoting attractiveness and altering appearances (USA Food, Drug and Cosmetic Act, 2012). These cover a wide range products including skin care creams, bath products, lotions, powders, perfumes, facial makeup and deodorants. An average person was reported to use up to 25 personal care products daily (Puah and Wan Jusoh, 2013). Despite the significant market demand of cosmetic and personal care products, the industry is very competitive and fast paced, requiring rapid product innovations (Kumar, 2005). While increased globalisation has opened window of opportunities, this phenomenon has also forced manufacturers to start targeting different market segments by developing and producing product lines dedicated for different sex, diverse age groups and ethnicities for business survival (Kumar et al. 2006; De Mooij and Hofstede, 2002). Recently, there is a growing interest in a new product - Halal cosmetics and personal care. Differs from the conventional product 
lines, the halal cosmetic brands do not contain porcine-by products and their derivatives as well as alcohol (Hashim and Mat Hashim 2013). They should be manufactured, stored, packaged and distributed according to Islamic teaching. The halal beauty products are also recognised as clean, safe and of high quality.

The growing market size of Muslim populations internationally, which has reached 2.04 billion in 2013 (Pew Research, 2013) are expected to create opportunities for the halal cosmetics and personal care industry. The rising economic power of Muslim countries have influenced them to spend more on beauty and personal goods(Swidi et al. 2010). Notwithstanding these, growing concerns over the environmental hazards has also significantly affected the cosmetic industry. Health hazards such as breast cancer, genital abnormalities and distortion which are associated with cosmetics products containing nano-particle ingredients, has caused rising consumer awareness concerning the substance of beauty products, creating demands for halal personal care and cosmetic goods (Kamaruzaman, 2009). Filipinos for instance, have started looking for halal goods as they believe that they are safer, healthier and good to be used.

Despite the potentials of this industry, consumers are not exposed sufficiently to halal brands, with relatively low level of responsiveness towards halal cosmetic products (Rajagopal et al. 2011). Halal issues within the sector remains minor concern among consumers as compared to food consumption. Hence, an understanding of how consumer perceives halal cosmetic brands is pertinent and should be explored further as this could facilitate manufacturers in producing and marketing their products effectively. Within the literature, most of the existing literature on halal matters have largely been conducted in the area of food science with studies focusing in the cosmetic industry have been largely neglected. Despite the existence of few studies (Hunter 2012; Musa 2014; Hussin 2013) on halal cosmetics, they relied on anecdotes and case studies with majority of them considered the contribution of theory of reason action (TRA) towards purchasing behaviour. While these studies do provide some insights, they cannot be conclusive. Viewing a discipline from multiple lenses, conceptual frameworks or theories is argued to be pertinent as it could create valuable insights (Shook et al. 2009; Feyerabend, 1975).

Motivated by the gaps identified above, this paper aims to determine the adoption of halal cosmetics among Muslims. In examining the factors that may affect their attitudes towards such product, this study expands prior research work by incorporating Diffusion of Innovation Theory. Innovation is defined as the generation, acceptance and implementation of new ideas, products or services in organisations, which provide improvement. Halal cosmetic is considered as an innovation in cosmetic industry, as it introduces new and different internal and external operations that could serve customer demands. Halal cosmetics concern on halal compliance that are applied to the entire supply chain ranging from the sourcing of raw materials to the manufacturing, transportation, warehousing and freights handling (Aoun and Tournois, 2015). As such, different procedures of producing, handling and managing products are needed. Manufacturers that wish to target the Islamic market, thus should take into account the specific religious requirements that reflect on different stages of product development. This study specifically examining how particular group - young Muslim consumers perceive halal cosmetics. Various literature highlight that cosmetic products are generally consumed for the purpose of impression creation and management in social context owing to their symbolic and communicative attributes (Khraim, 2011; Chen et al. 2011), making it more pertinent and appealing to the cohort of young adult consumers, who are found to be more consumption oriented, socially conscious and open to multiculturalism (Hewlett et al. 2009). Within the context of Malaysia for instance, they represent the prime market for clothing and personal care products (Yusof and 
Duasa, 2010).

The Malaysian halal cosmetic industry has existed since 1980, with a strong growth recently contributing 10 to 20 per cent of the total local cosmetics market. The industry is worth approximately USD800 million, with an annual growth rate of 24 per cent (Halal Industry Development Corporation, 2014). In the year 2013, the export of Malaysian halal cosmetic products was approximately at RM 464.45 million, with destinations such as the United States, the Middle East, China, ASEAN and Europe being the major markets. In 2011, there were 114 local manufacturers in the industry certified as halal(Boo, 2013). Among the market leader in this sector include Unza, Clara international Beauty Group Sdn. Bhd., SendayuTinggi Holdings SdnBhd and SimplysitySdn Bhd. Hence, it is interesting to note that halal cosmetic industry has become one of the vital economic sectors of the Malaysian economy. Notwithstanding this, Malaysia has also attracted a huge number of leading foreign cosmetic manufacturers Procter \& Gamble, Unilever, L'Oreal and Colgate-Palmolive to establish their manufacturing facilities in the country, driving foreign exchange earnings and employment opportunities. In Malaysia, the halal cosmetic products are governed by the Malaysian Standard MS 2200:2008 and Halal Certification Procedure Manual, which warrant strict manufacturing facilities inspection and audit by the Malaysian Department of Islamic Development (JAKIM) (Hashim and Mat Hashim 2013). Owing to the interesting development of Malaysian halal cosmetic industry, it is imperative to understand how the young Muslim consumers perceive the halal cosmetics and what factors affecting their adoption decision, as this could positively facilitate the manufacturers in producing and marketing products effectively.

\section{Conceptual Development}

Diffusion of Innovation (DOI) Theory seeks to explain how, why and at what rate new ideas are spread through cultures. The theory asserts that perceived innovation characteristics, social influence and individual innovativeness may influence an individual adoption of innovation.

Forty-nine to eighty per cent of the variance in rate of innovation adoption is explained by innovation characteristics, which include its perceived relative advantage, compatibility and complexity. Relative advantage refers to the degree to which an innovation is perceived as being better than the idea it supersedes. Prior researches have associated halal cosmeticsas a symbol of cleanliness, safety and of high quality, since the production of these goods need to be carried out under strict hygienic conditions according to Good Manufacturing Practice (GMP) and Public Health Legislations (Amat, 2006; Hashim and Mat Hashim, 2013). Since the halal cosmetic goods are not tested on animals and are produced using natural ingredients that are kind to hair and skin, they could also appeal not only for Muslims, yet to non-Muslim consumers as well. Notwithstanding these, compatibility, which refers to the degree to which an innovation fit the individual cultures may also induce them to adopt the new product. Within the context of halal cosmetics, Muslim consumer may repeat the purchase if the attributes of the products such as their ingredients, texture and performance aspects are conformed to their cultural requirements and personal taste (Khraim, 2011). Product characteristics that are incongruent with Islamic values may lead to cultural conflicts and ethical dilemmas. For Muslim consumers, the cosmetics and personal care products not only need to be complied with government safety regulations, yet they are required to be halal.For instance, while the use of keratin (taken from hair), albumin (human serum), and placenta (womb) are common in conventional cosmetic production, these substance are not allowed to be utilised in halal cosmetic manufacturing process as they are taken from human parts. The halal-ness of these goods are pertinent since they affect the worship and prayers of Muslims. They may have religiously 
informed expectations of the products, which if inadequately accommodated will create poor customer satisfaction. Similarly, potential adopters may also evaluate the innovation based on its complexity, which refers to the degree of difficulties associated with adopting the innovation, required resources and cognitive efforts. This suggests that the difficulties in gaining the access to halal cosmetics in the market would affect consumers' purchasing decisions. The absence of halal logo on the products for instance may require consumers a great deal of time and cognitive efforts to browse through the ingredients before making purchasing decisions. Given these arguments, this study postulates that:

$\mathrm{H}_{1}$. Products' characteristics are positively related to halal cosmetics adoption

Social influence which originates from psychological studies, refer to a change of thinking or feeling of individuals reflected on their behaviour owing to the relationship with others (Pavalou and Chai, 2002; Montalvo, 2006; Woolthuis et al. 2005). This suggests that even though a person might not have a constructive attitude towards halal cosmetics, the incongruence between his or her attitude and family or friends' expectations may influence his or her behaviour. They may embark on purchasing halal cosmetics to ensure their legitimacy, since they may look for a balance between their actions and how they are perceived by others. Based on these arguments, this study postulates that:

$\mathrm{H}_{2}$. Social influence are positively related to halal cosmetics adoption

Innovativeness is defined as the degree of individual willingness to adopt new ideas earlier that other members in a society (Rogers, 2003). This dimension appears to receive widespread attention from consumer and marketing studies (Tajeddini, 2010; Hirunyawipada and Paswan, 2006; Phau and Cheong 2009), since innovators are considered as important factors in new products diffusion and adoption (Bhate and Lawler, 1997).Within the halal industry, consumers who are more open to new experience may have little trouble changing their daily routine from using nonhalal to halal personal care products. They may habitually enjoy searching for information about potential benefits of halal cosmetic brands and may also influence other shoppers' product choices by sharing their knowledge (Kim et al. 2010). As most consumers do not possess sufficient knowledge about the potential benefits associated with new cosmetic goods such as halal cosmetics, only bold individuals who are more innovative will be more willing to invest time, money and take risks to try out different products. Given these arguments, this study postulates that:

$\mathrm{H}_{3}$. Consumer innovativenessis positively related to halal cosmetics adoption

While the DOI theory has a solid theoretical foundation to predict innovation adoption, a model solely based on this theory may not be able to fully capture the insights. Some researchers in the halal discipline suggest religion as pertinent factor that may influence people's attitudes, values and behaviours at both individual and societal levels (Mokhlis, 2009; Shah Alamet al. 2011). Religion could be defined as a set of beliefs that are imparted since childhood and will gradually impacted a person's life as the understanding towards its teaching grow. In light of this, we incorporate religiosity which could be defined as the extent to which an individual has incorporated the tenets of a particular religion into his/her attitudes, beliefs and values (King and Williamson, 2005). Highly religious society members may tend to perceive the world based on religious dimensions and values. Within the Muslim culture, the adoption of cosmetics goods may differ depending on the level of religiosity. For instance, stricter Muslim consumers may reject the use of ethanol in fine perfume, while some Islamic followers may not express concerns as the alcohol is used not for oral consumption (Hunter, 2012). Muslim consumers with higher religiosity values may also tend to be more 
concern on how others in the Islamic society evaluate them. Hence, an individual can devalue the product characteristics, social factors and innovativeness with respect to religion. Given these arguments, this study postulates that: $H_{4 a}$ Religiosity moderates the relationship between product characteristics and halal cosmetics adoption

$H_{4 b}$ Religiosity moderates the relationship between social influence and halal cosmetics adoption

$H_{4 c}$ Religiosity moderates the relationship between consumer innovativeness and halal cosmetics adoption

Drawing upon the existing literature and hypotheses development, a conceptual model (Figure 1) is established. This model suggests that the adoption of halal cosmetics is influenced by innovation characteristics, social influence and consumer innovativeness. The model also suggests that the relationship between the three predictor variables and halal cosmetics adoption is moderated by religiosity.

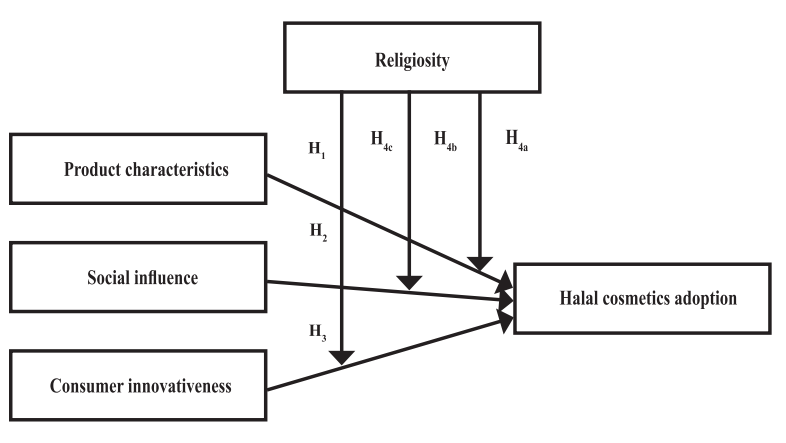

Figure 1

\section{Methodology}

The constructs used in this study are measures from the literature which were adapted to the context of this study. Innovation characteristics was measured using 11 items, which evaluate how consumers perceived the benefits of halal cosmetics as compared to the conventional and the suitability of products with their lifestyle as well as difficulties encountered in using such goods. Social influence was measured using four items, which evaluate the extent of halal cosmetic usage among peers and family. Innovativeness was evaluated using four items that measure the degree of respondents' willingness to try new products. These items were adapted from Rogers (2005) and modified accordingly so that the focus was on halal. Intention to use Halal cosmetics adoption were measured using five items adapted from Lada et al. (2009) and Mukhtar and Butt (2012). Six items measuring the religious commitment of respondents were adapted from Mohklis (2009). These items evaluated how well the consumers have integrated the Islamic values in their daily life. All the questions used a 7-point Likert scale ranging from 1 "strongly disagree" to 7 "strongly agree".

This study employed a survey method, using a questionnaire to test the conceptual model and hypotheses developed. The survey was conducted in Kuala Lumpur in March 2015 in a number of supermarkets. In the process of collecting data, convenience sampling method was utilised. The prospective respondents were politely approached by researchers who described the study and sought their approval to be considered as part of the participants. Researchers also emphasised that the data collected would be exclusively used for research purposes and their participation was anonymous and voluntary. Respondents completed the questionnaire and handed to the researcher. A total of 500 questionnaires were distributed with 238returned, expressing a response rate of 46.4 per cent. As indicated in Table 1, majority of the respondents are female (72.3 per cent) and possess tertiary education (87.3 per cent), with more than half ( 77.3 per cent) earn below RM 3,000. Most of the samples in this study are between 20-25 years old. 
GJAT | JUNE 2016 | VOL 6 ISSUE 1 | 52

ISSN : 2232-0474 | E-ISSN : 2232-0482

www.gjat.my

Table 1 Sample characteristics

\begin{tabular}{|c|c|c|c|}
\hline \multicolumn{2}{|c|}{ Demographic } & Frequency & 27.7 \\
\hline \multirow{2}{*}{ Gender } & Male & 66 & 72.3 \\
\hline & Female & 172 & 3.8 \\
& $17-18$ & 9 & 4.2 \\
Age (years) & $19-20$ & 10 & 6.3 \\
& $21-22$ & 15 & 10.9 \\
& $23-24$ & 26 & 74.8 \\
\hline Income level & $24-25$ & 178 & 8.8 \\
\hline & $<2000$ & 22 & 68.5 \\
\hline & $2000-3000$ & 167 & 3.4 \\
\hline & $3000-4000$ & 8 & 12.6 \\
\hline & Secondary school & 30 & 71.8 \\
\hline
\end{tabular}

\section{Results and Discussion}

A measurement model, comprising all the construct of interests was evaluated. Two psychometric tests - validity and reliability were performed based on the full measurement model generated. As shown in Table 2, all the constructs had composite reliability $(\mathrm{CR})$ values of greater than the threshold point of 0.7 (Hair et al. 2013). In addition to composite reliability, the average variance extracted (AVE) of these constructs achieved the cut-off point, indicating a satisfactory degree of reliability. We also tested discriminant validity using Fornell and Larcker (1981) approach. All the scales appeared to have a substantially higher AVE value compared to their correlation with other constructs, providing evidence of discriminant validity (Table 3). Additionally, all the factor loadings of items were above 0.6 , at significant at $p<.001$, demonstrating a good convergent validity (Table 2). The result of the measurement model indicate that various validity and reliability criteria are satisfied. Therefore, constructs developed in this measurement model could be used to test the structural model and the associated hypotheses. 
Table 2 Measurement model

\begin{tabular}{|c|c|c|c|c|}
\hline Constructs & Items & Factor Loadings & $\mathrm{CR}$ & AVE \\
\hline \multirow{7}{*}{ Product characteristics } & $\begin{array}{l}\text { Halal cosmetics/personal care are pure } \\
\text { and clean }\end{array}$ & 0.796 & \multirow{7}{*}{0.861} & \multirow{7}{*}{0.734} \\
\hline & $\begin{array}{l}\text { Halal cosmetics/personal care preserve } \\
\text { nobility of human body }\end{array}$ & 0.770 & & \\
\hline & $\begin{array}{l}\text { Halal cosmetics/personal care are } \\
\text { good quality and safe }\end{array}$ & 0.815 & & \\
\hline & $\begin{array}{l}\text { As a Muslim, it is important for me to } \\
\text { purchase halal cosmetics/personal care }\end{array}$ & 0.788 & & \\
\hline & $\begin{array}{l}\text { I prefer halal cosmetic/personal care } \\
\text { in my daily life as it conforms to my } \\
\text { religious value }\end{array}$ & 0.656 & & \\
\hline & $\begin{array}{l}\text { I always choose halal even if not } \\
\text { familiar with the cosmetic/personal } \\
\text { care brand }\end{array}$ & 0.719 & & \\
\hline & $\begin{array}{l}\text { It is difficult to spot halal/non-halal } \\
\text { cosmetics due to unclear packaging } \\
\text { labels indicating the ingredients }\end{array}$ & 0.608 & & \\
\hline \multirow{4}{*}{ Social Influence } & $\begin{array}{l}\text { Most people around me use halal } \\
\text { cosmetics/personal care products }\end{array}$ & 0.769 & \multirow{4}{*}{0.868} & \multirow{4}{*}{0.801} \\
\hline & $\begin{array}{l}\text { When it comes to a matter of choosing } \\
\text { cosmetics/personal care products, I } \\
\text { would like to be like my friends }\end{array}$ & 0.824 & & \\
\hline & $\begin{array}{l}\text { I choose halal cosmetics/personal care } \\
\text { products based on recommendations } \\
\text { from friends and relatives. }\end{array}$ & 0.824 & & \\
\hline & $\begin{array}{l}\text { People who I listen to could influence } \\
\text { me to use halal cosmetics/personal } \\
\text { care products }\end{array}$ & 0.787 & & \\
\hline \multirow{4}{*}{ Individual Innovativeness } & $\begin{array}{l}\text { I spend little time exploring new } \\
\text { cosmetics/personal care products }\end{array}$ & 0.642 & \multirow{4}{*}{0.814} & \multirow{4}{*}{0.641} \\
\hline & $\begin{array}{l}\text { I am hesitant to try new product } \\
\text { cosmetics/personal care }\end{array}$ & 0.640 & & \\
\hline & $\begin{array}{l}\text { Among peers, I am usually the first } \\
\text { to try new cosmetics/personal care } \\
\text { products }\end{array}$ & 0.661 & & \\
\hline & $\begin{array}{l}\text { I like to experiment new cosmetics/ } \\
\text { personal care product }\end{array}$ & 0.623 & & \\
\hline \multirow{6}{*}{ Religiosity } & I regularly pray five times a day & 0.716 & \multirow{6}{*}{0.859} & \multirow{6}{*}{0.707} \\
\hline & I fast regularly during Ramadhan & 0.597 & & \\
\hline & I regularly recite the Holy Quran & 0.768 & & \\
\hline & $\begin{array}{l}\text { I pay zakat every year if I meet the } \\
\text { prescribed criteria }\end{array}$ & 0.583 & & \\
\hline & $\begin{array}{l}\text { I try to follow Islamic conjunctions in } \\
\text { all matters of my life }\end{array}$ & 0.795 & & \\
\hline & $\begin{array}{l}\text { I always try to avoid minor and major } \\
\text { sin }\end{array}$ & 0.785 & & \\
\hline \multirow{4}{*}{ halal cosmetics adoption } & $\begin{array}{l}\text { I prefer to use halal cosmetics/ } \\
\text { personal care product }\end{array}$ & 0.781 & \multirow{4}{*}{0.881} & \multirow{4}{*}{0.806} \\
\hline & $\begin{array}{l}\text { I will not purchase or use a product if } \\
\text { doubt with the ingredients }\end{array}$ & 0.781 & & \\
\hline & $\begin{array}{l}\text { I prefer to use halal cosmetics/ } \\
\text { personal care products even if it is } \\
\text { more expensive }\end{array}$ & 0.832 & & \\
\hline & $\begin{array}{l}\text { I prefer to use halal cosmetics/ } \\
\text { personal care products even if } \\
\text { the sales promoter promotes the } \\
\text { conventional products }\end{array}$ & 0.829 & & \\
\hline
\end{tabular}


GJAT | JUNE 2016 | VOL 6 ISSUE 1 | 54

ISSN : 2232-0474 | E-ISSN : 2232-0482

www.gjat.my

Table 3 Discriminant validity

\begin{tabular}{|l|l|l|l|l|l|l|l|}
\hline & Mean & SD & PC & SI & II & RL & HC \\
\hline Product characteristics (PC) & 4.22 & 1.15 & $\mathbf{0 . 8 6}$ & & & & \\
\hline Social influence (SI) & 3.70 & 1.07 & 0.46 & $\mathbf{0 . 8 9}$ & & & \\
\hline Individual innovativeness (II) & 3.46 & 1.76 & 0.10 & 0.30 & $\mathbf{0 . 8 0}$ & & \\
\hline Religiosity (RL) & 4.09 & 0.92 & 0.41 & 0.24 & 0.40 & $\mathbf{0 . 8 4}$ & \\
\hline Halal cosmetics adoption (HC) & 4.06 & 1.10 & 0.46 & 0.78 & 0.41 & 0.70 & $\mathbf{0 . 9 0}$ \\
\hline
\end{tabular}

Assuming that the measurement model satisfied the psychometric assessment, a structural model was constructed based on the results of the measurement model. The predictive accuracy of the model was evaluated in terms of the portion of variance explained. The results suggest that the model is capable of explaining $48.9 \%$ of the variance in halal cosmetics adoption. Nonparametric bootstrapping was applied (Wetzels et al., 2009) with 2000 replications to test the structural model. As suggested by Chin et al. (2003), we employ a hierarchical approach to test our hypotheses, in which we first estimate a model with the main effects (and covariates) only and then add the interaction effects. The results indicate that the effects of product characteristics $(\beta=0.187, p<0.01)$ social influence $(\beta=0.129, p<0.01)$ and consumer innovativeness $(\beta=0.14, p<0.01)$ on halal cosmetics adoption are significant and positive (Table 4). As such, $\mathrm{H}_{1}, \mathrm{H}_{2}$ and $\mathrm{H}_{3}$ are supported.With regard to the moderating hypotheses, we find that all interaction effects are significant at $p<0.01$, hence supporting $\mathrm{H}_{4 \mathrm{a}}$, $\mathrm{H}_{4 \mathrm{~b}}$ and $\mathrm{H}_{4 \mathrm{c}}$. The $\mathrm{R}^{2}$ for the value of the halal cosmetics adoption in the final model (including both main and interaction effects) is .51.

This study incorporates religiosity and diffusion of innovation (DOI) theory to form an integrative framework for investigating some of the key issues related to halal cosmetics adoption among young Muslim consumers in Malaysia. The impetus for the conception of

this study is provided by the lack of academic inquiry into the halal cosmetics adoption from the perspective of innovation adoption research such as DOI theory. Extending prior works on halal cosmetics, this study views such product as innovation since innovation is not only limited to technological breakthrough, yet the concept could occur within services, processes or any social systems (Flint et al. 2005). Promoting halal goods such as halal cosmetics and personal care products is considered an innovation as it introduces new procedures of producing, handling and managing products, illustrating DOI theory as a valid model of prediction. Within the DOI theory, three variables explored in this study-product characteristics, consumer innovativeness and social influence are found to be congruent with existing studies.

The significant role of product characteristics as a key determinant in halal cosmetics adoption concludes that consumers in this study appear hesitant to use halal products if there are no perceived potential benefits and do not suit their lifestyle and culture. The halal cosmetics which are associated with a symbol of cleanliness, safety and of high quality have attracted the respondents to adopt such products. Since the production of halal cosmeticsnot only confine to the standards of quality, safety and wholesomeness as allowed in Islam(Che Man et al. 2009), yet need to be produced under strict hygienic conditions according to Good Manufacturing Practice (GMP) and Public Health Legislations (Amat, 2006; Hashim and Mat Hashim, 2013) they may not only be used by Muslims, yet non-Muslims too. The fact of the matter is, Muslim consumers' consumption patterns are also similar to other market segments as they demanding healthy and quality cosmetic goods, which must also conform to Shariah requirements. Being a young generation, the respondents in this study are 


\begin{tabular}{|c|c|c|c|}
\hline Hypothesis & Relationship & Path Coefficient & Decision \\
\hline \multicolumn{4}{|l|}{ Direct Effect } \\
\hline $\mathrm{H}_{1}$ & $\mathrm{PC}->\mathrm{HC}$ & $0.187 * *$ & Supported \\
\hline $\mathrm{H}_{2}$ & $\mathrm{SI}->\mathrm{HC}$ & $0.129 * *$ & Supported \\
\hline $\mathrm{H}_{3}$ & $\mathrm{CI}->\mathrm{HC}$ & $0.140^{* *}$ & Supported \\
\hline \multicolumn{4}{|c|}{ Moderating Effect of Religiosity } \\
\hline $\mathrm{H}_{4 \mathrm{a}}$ & $\mathrm{PC}->\mathrm{HC}$ & $0.195^{* * *}$ & Supported \\
\hline $\mathbf{H}_{4 \mathrm{~b}}$ & $\mathrm{SI}->\mathrm{HC}$ & $0.132 * *$ & Supported \\
\hline $\mathbf{H}_{4 \mathrm{c}}$ & $\mathrm{CI}->\mathrm{HC}$ & $0.151^{* *}$ & Supported \\
\hline
\end{tabular}

$* * * \mathrm{p}<0.001, * * \mathrm{p}<0.01$

well educated and would search for product information to check whether the product fits their needs (Eze et al. 2012).Occasionally, many Muslim consumers depend greatly on the labels on the outer packaging in facilitating them to select halal cosmetics (Zakaria, 2008). Yet, with various products available on the market written in their scientific nomenclature, the adoption of halal cosmetics products may become complex without proper halal label or illegitimate use of halal logo.

In this study, we also found that consumers' adoption of halal cosmetics is also shaped by social pressure and the opinion of their reference group such as family and friends. Perceived opinion or belief from the closer and important people to the respondents may help them build confidence and gain knowledge on the halal cosmetics attributes. This is not surprising since Malaysia is a Muslim countries, with large local Muslim populations, in which halal products are consumed and more accepted by the societies. As discussed in the theory development section, consumers' adoption of new products are driven by the need to attain social approval and recognition(Pavalou and Chai, 2002). Our findings support this assertion and suggest that the need to improve social standing will drive the young Muslim consumers toward being constantly aware about halal cosmetics products. Ability to convey and reflect a good self-image to others in the social context is particularly important for this generation (Jackson et al. 2011).
Previous literature have indicated the importance of individual innovativeness in influencing innovation adoption(Tajeddini, 2010; Hirunyawipada and Paswan, 2006).Consumers who are conscious about their appearance may have a strong awareness on the beauty products enabling them to discern the hots from the nots which enabling them to enhance their social standing. In this study,consumer innovativeness is found to be a significant factor, suggesting that Muslim consumers appeared to adopt halal cosmetics, based on the level of their innovativeness. Being a young generation, these respondents are found to be more accessible to information and thus consists of innovative consumers who would react proactively towards such new product innovation. Many Muslims would be more concerned about the presence of non-halal materials used in cosmetics production and willing to change their daily routine from using non-halal to halal beauty products. While there is an authoritative body to check and monitor the halal status, it is the inherent duty of every Islamic followers to ensure that what they consume originates from halal sources, requiring them to gain information on the products' attributes, influencing their level of innovativeness.

Studies concerning the halal products have considered religiosity as factor that may influence the consumer preferences (Mokhlis, 2009; Shah Alamet al. 2011). Our findings reported religiosity as moderator. We found 
that respondents who are more devoted to religion may incorporate these beliefs and values into their daily life, influencing them to focus more on the product attributes, social influence and innovativeness when deciding to adopt halal cosmetics. Religious consumers may have relatively high levels of product category knowledge and be able to evaluate brands on fairly objective level based on the product attributes. This finding also suggest that religious consumers may be involved in a community in which religious play a role in their daily life. Being engaged in this community might influence their attitude towards halal cosmetics as they need to ensure their legitimacy.

\section{Conclusion}

This study offers theoretical and practical contributions by demonstrating the applicability of DOI theory and religiosity dimension to evaluate the factors affecting halal cosmetic adoption among young Muslim consumers in Malaysia. The misconception of halal being relevant only to food consumption and financial transactions is changing as more businesses outside this industry are entering the halal market. The growing Muslim populations and their purchasing power as well as heightened demand for novel cosmetics products such as halal beauty goods and personal care create a need for businesses to start considering the market.

Despite the economic potentials, the production of halal cosmetics is not a simple tasks. Our findings imply that the manufacturers should be aware of the fact that consumers often evaluate the attributes of the products to determine the quality, safety and health values before purchase and adopt new cosmetics goods. This suggests that manufacturers need to concentrate on providing new value added products continuously. While the new wave of product marketing will originate from the Islamic world, yet the halal cosmetic goods should address universal values that resonate with human kind instead of selling Islam to Muslims. They have to represent their beauty goods as not only conform to Islamic law, yet they are in harmony with the ethical and animal welfare concerns of discerning consumers worldwide. This image could appeal strongly to non-Muslim markets. Product attributes play an important role in marketing strategies, and they emerge as a good communication media between consumers and marketers. Manufacturers and marketers therefore should be able to link product attributes not only to physical characteristics, yet to benefits of purchasing and consuming the goods. This is pertinent as product attribute could be used by the marketer to set the brand aside from competitors, as consumers make purchasing decision based on perceived goods' characteristics. The manufacturers need to also exploit halal certification and logo as a method to inform and restore consumers' confidence that their products complies with Islamic law, creating a competitive advantage over competitors who do not possess such certifications. Having the product certified as halal could to a certain extent create market niche as well as quality and price advantages. Most importantly, such move could reduce consumers' cognitive efforts to browse through the various cosmetic ingredients to assure the halal-ness of the product, which in turn could reduce the complexity. Using Muslim celebrities for endorsing halal cosmetics may also facilitate firms in attracting the market segment, since the young Muslim consumers are found to be more conscious on their social status.

Despite that this study expand prior research on halal cosmetics industry, the present research has some limitations. Our data only confined to the voices of those generation Y Muslim consumers. A more heterogeneous sample of different individuals with various levels of disposable income, education and age might be a better predictor. Hence, the findings may not be generalised as representative in Malaysia. Nevertheless, this work represents a first approximation to better understand Muslim consumers' values and needs of halal cosmetics 
based on the innovation adoption research and religiosity perspective. It is hoped that this paper has succeeded in providing empirical evidence of halal cosmetics adoption in Malaysia. Insights gleaned from this study could facilitate industry practitioners in improving cultural competence and providing superior halal cosmetics products to this culturally sensitive market segments, leading to growing market size.

\section{Acknowledgements (Optional)}

This paper is based on a research which is financially supported by the University of Malaya- (UMRG) SBS (Equitable Society)grant no. RP016A-13SBS

\section{References}

Amat, S., "Halal-new market opportunities", The 9th Efficient Consumer Response (ECR)

Conference. KualaLumpur Convention Centre (KLCC), Kuala Lumpur,Malaysia, 2006.

Anderson, J.C. \&Gerbing D.W.(1988).Structural Equation Modelling in Practice: A Review and Recommended Two- Step Approach. Psychological Bulletin, 103, 411-423.

Boo, S. L. (2013), With halal makeup, piety in a jar, TheMalaymail online. Retrieved on July 2014 fromhttp://m.themalaymailonline.com/ malaysia/article/with-halal-makeup-piety-ina-jar

Bhate, S., \& Lawler, K. (1997). Environmentally friendly products: factors that influence their adoption. Technovation, 17(8), 457-465.

Montalvo, C. (2006). What triggers change and innovation?.Technovation, 26(3), 312-323.

Che Man, Y. \& S. Mustafa, (2010). Updates of halal products authentication. Presentation slides at world halal research summit 2010. Malaysia: Kuala Lumpur
Chen C.W., Chen T.H.,\& Lin Y.F., 2011, Statistical analysis for consumers' intensions of purchasing cosmetics. South African Journal of Business Management, 5, 20, 8271-8276

De Mooij, M., \& Hofstede, G. (2002). Convergence and divergence in consumer behavior: implications for international retailing. Journal of retailing, 78(1), 61-69.

Eze, U. C. (2012). The influence of quality, marketing and knowledge capabilities on business competitiveness. International Journal on Innovation and Learning, 11(3), 288-307.

Feyerabend, P. (1975). "Against Method". Lowe and Brydone. Thetford, UK

Flint, D.J., Larson, E., Gammelgaard, B., \&Mentzer, J.T. (2005), "Logistics Innovation: A Customer Value-Oriented Social Process" Journal of Business Logistics, 26(1),113-147

Fornell, C.\&Larcker, D.F., 1981. Evaluating structural equation models with unobservable variables and measurement error. Journal of Marketing Research 18 (1),39-50

Hair, J.F., Hult, G.T.M., Ringle, C.M., \&Sarstedt, M. (2013). A Primer on Partial Least Squares Structural Equation Modelling (PLS-SEM). Thousand Oaks: Sage.

Halal Industry Development Corporation (2014). Opportunities in halal economy. Halal Industry Development Corporation. Retrieved on July 2014 from http://www.kccci.org.my/ attachments/article/1921/Opportunies_in_ Halal_Economy.pdf.

Hashim, P., \& Mat Hashim, D. (2013) A Review of Cosmetic and Personal Care Products: Halal Perspective and Detection of Ingredient, Pertanika Journal Science \& Technology, 21(2),281-292.

Hewlett, S. A., Sherbin, L., \&Sumberg, K. (2009). How gen Y \& boomers will reshape 
your agenda. Harvard Business Review, 87(7), 71-76.

Hirunyawipada, T., \&Paswan, A. K. (2006). Consumer innovativeness and perceived risk: implications for high technology product adoption. Journal of Consumer Marketing, 23 (4), 182-198

Howe, N. \& W. Strauss. (2007). Millennials Go to College, 2nd ed. lifeCourse associates

Hunter, M. (2012). The emerging Halal cosmetic and personal care market. Personal Care, 37-41.

Hussin, S.R., H. Hashim, R.N. Yusof\& N.N. Alias, 2013. Relationship between product factors, advertising, and purchase intention of halal cosmetic. Pertanika Journals of Social Sciences \& Humanities, 21(5): 85-100

Jackson, V., Stoel, L., \& Brantley, A. (2011). Mall attributes and shopping value: Differences by gender and generational cohort. Journal of retailing and consumer services, 18(1), 1-9.

Kamaruzaman, K. A. 2009. Halal cosmetics: Between real concerns and plain ignorance [online] Available at: http://halaljournal.com [Accessed 23 December 2012

Khraim H.S., 2011, The influence of brand loyalty on cosmetics buying bahavior of UAE female consumers. International Journal of Marketing Studies, 3(2):123-133

Kim, K. H., \& Kim, D. H. (2010). Research Reports : A Study on the Attitude toward Makeup Cosmetics by Fashion Leadership -Ranging in Silver Generation Women. Journal of the Korean Society of Design Culture, 16(4), 5268 .

King, J.E. \& Williamson, I.O. (2005). Workplace Religious Expression, Religiosity and Job Satisfaction: Clarifying a Relationship. Journal of Management, Spirituality and Religion, 2, 173-198
Kumar, S. (2005). Exploratory analysis of global cosmetic industry: major players, technology and market trends. Technovation, 25(11), 12631272.

Kumar, S., Massie, C., \&Dumonceaux, M. D. (2006). Comparative innovative business strategies of major players in cosmetic industry. Industrial Management \& Data Systems, 106(3), 285-306.

Lada, S, Geoffrey, H.T. \&Hanudin, A. (2009) "Predicting intention to choose halal product using theory of reasoned action". International Journal of Islamic and Middle Eastern Finance and Management, 2(1), 66-76

Mokhlis, (2009). Religious Differences in Some Selected Aspects of Consumer Behaviour: A Malaysian Study

Mukhtar, A., \& Butt, M.M. (2012). Intention to choose halal products: The role of religiosity. Journal of Islamic Marketing, 3(2), 108-120.

Pavlou, P.A. \& L. Chai, (2002)"What Drives Electronic Commerce across Cultures? AcrossCultural Empirical Investigation of the Theory of Planned Behavior, Journal of Electronic Commerce Research, 3(4):240-253,

PewResearch (2013). The Worlds's Muslims: Religion, Politics and Society. Pew Research Centre. Retrieved on July 2014 from http:// www.pewforum.org/2011/01/27/the-future-ofthe-global-muslim-population/

Phau, I., \&Cheong, E. (2009). Young consumers' evaluations of diffusion brands. Young Consumers, 10(3), 210-224.

Rajagopal S., Ramanan S., Visvanathan R., \& Satapathy S. (2011). Halal certification: implication for marketers I UAE. Journal Islamic Marketing. 2(2); 138-153.

Rogers, E.M. (2003). Diffusion of innovations(5thed.). New York: Free Press. 
Shook, C.L., Adams, G.L., Ketchen, D.J. Jr \&Craighead,C.W. (2009), "Towards a "the Oretical toolbox' for strategic sourcing, ,Supply Chain Management: an International Journal,14(1): 3-10.

Swidi, A, Wie, C, Hassan MG, Al-Hosam, A. \&MohdKassim, AW (2010). The mainstream cosmetics industry in Malaysia and the emergence, growth and prospects of Halal cosmetics. The Third International Conference on International Studies (ICIS 2010),Sintok: Universiti Utara Malaysia.

Shah Alam, S., \& Mohamed Sayuti, N. (2011). Applying the Theory of Planned Behavior (TPB) in halal food purchasing. International Journal of Commerce and Management, 21(1), 8-20.

Tajeddini, K. (2010). Effect of customer orientation and entrepreneurial 100 orientation on innovativeness: Evidence from the hotel industry in Switzerland. Tourism Management, $31(2), 221-231$

Teng, P. K., \& Wan Jusoh, W. J. (2013). Investigating student awareness and usage intention towards Halal labelled cosmetics and personal care products in Malaysia. In 4th International Conference on Business and Economic Research (4th ICBER 2013), Indonesia: Bandung.

USA Food, Drug and Cosmetic Act 2012. US Food and Drugs Administration (FDA). Retrieved on May 2015 at http://www.fda. gov/RegulatoryInformation/Legislation/ FederalFoodDrugandCosmeticActFDCAct/ SignificantAmendmentstotheFDCAct/FDASIA/

Wetzels, M., Odekerken-Schroder, G., \& van Oppen, C. 2009. "Using PLS Path Modeling for Assessing Hierarchical Construct Models:Guidelines and Empirical Illustration," MIS Quarterly(33:1), pp. 177-195

Woolthuis, R. K., Lankhuizen, M., \&Gilsing, V. (2005). A system failure framework for innovation policy design. Technovation, 25(6), 609-619.

Yusof, S. A., \&Duasa, J. (2010). Consumption Patterns and Income Elasticities in Malaysia. Malaysian Journal of Economic Studies, 47(2), 91-106

ZalinaZakaria,(2008), Tapping into the World halal Market: Some discussions on the Malaysian Laws,. Shariah Journal, vol.16, special Edition, p. 603-616. 
